\title{
PENGEMBANGAN BAHAN AJAR PEMBUATAN SULAMAN TIMBUL PADA MATA KULIAH SULAMAN UNIVERSITAS NEGERI PADANG
}

\author{
Ira Syafrina ${ }^{1^{*}}$, Weni Nelmira ${ }^{2^{*}}$ \\ Program Studi Pendidikan Kesejahteraan Keluarga Jurusan Ilmu Kesejahteraan Keluarga \\ Fakultas Pariwisata dan Perhotelan \\ Universitas Negeri Padang \\ Jl. Prof. Dr. Hamta, Air Tawar Padang, Kel. Air Tawar Barat, Kec. Padang Utara, Kota Padang, Kode Pos 25171 \\ Sumatera Barat. Indonesia \\ Email: irasyafrina0809@gmail.com
}

\begin{abstract}
Abstrak
Penelitian ini dilatar belakangi untuk mengatasi permasalahan mahasiswa dalam perkuliahan Sulaman pada materi membuat sulaman timbul, dimana masih terbatasnya referensi mengenai materi Membuat Sulaman Timbul. Tujuan dari penelitian ini untuk menghasilkan media pembelajaran berupa bahan ajar yang valid dan praktis. Penelitian ini merupakan penelitian Research and Development $(R \& D)$. Prosedur penelitian menggunakan model 4-D yang terdiri dari tahap pendefenisian (Define), tahap perancangan (Design), tahap pengembangan (Develop) dan tahap (Disseminate). Namun dalam penelitian ini desseminate tidak digunakan karena mengingat keterbatasan peneliti. Data diperoleh dari uji validitas, uji praktikalitas dosen pembina mata kuliah, uji praktikalitas kelompok kecil dan uji praktikalitas kelompok besar. Validator terdiri atas validasi media dan validasi materi yang berjumlah 4 orang. Berdasarkan hasil uji validitas bahan ajar Sulaman diperoleh skor rata-rata 4,35 dengan kategori sangat valid. Selanjutnya dari hasil uji praktikalitas diperoleh skor $85 \%$ dengan kategori sangat praktis. Maka dapat disimpulkan bahwa bahan ajar ini layak digunakan sebagai media pembelajaran sulaman timbul.
\end{abstract}

Kata Kunci: bahan, ajar, sulaman, timbul.

\begin{abstract}
This research aims to solve the problems of students lectures of embroidery on embroidered embroidery material. There are still limited references to the material of Making Embossed Embroideries. The purpose of this study is to produce learning media that contain valid and practical teaching materials. This research is a Research and Development $(R \& D)$ research. The research procedure uses a 4-D model consisting of defining (definition), per-design, development design, and development (dissemination). But in this study, it was not used as a consideration for research. Data were obtained from validity tests, practicality tests of lecturer advisors, small group practicality tests and large group practicality tests. The validator consists of media validation and material validation collected by 4 people. Based on the results of the validity test of Sulaman teaching materials obtained an average score of 4.35 with a very valid category. Furthermore, from the practicality test results obtained a score of $85 \%$ with a very practical category. It can be concluded that teaching materials are suitable to be used as embroidery learning media arise.
\end{abstract}

Keywords: teaching, materials, embossed, embroideries.

\section{PENDAHULUAN}

Faktor yang mempengaruhi proses pembelajaran salah satunya adalah media pembelajaran yang digunakan. Media pembelajaran merupakan segala sesuatu yang dapat digunakan untuk menyalurkan pesan pengirim ke penerima sehingga merangsang pikiran, perasaan, perhatian, dan minat serta kemauan peserta didik sedemikian rupa, sehingga proses belajar terjadi dalam rangka mencapai tujuan pembelajaran yang efektif.
Program Studi Tata Busana (D3) merupakan salah satu program studi pada jurusan Ilmu Kesejahteraan Keluarga FPP UNP. Pada kurikulum Prodi Tata Busana mahasiswa diwajibkan untuk mengikuti sejumlah mata kuliah. Mata kuliah Sulaman merupakan salah satu mata kuliah wajib yang diikuti oleh mahasiswa pada semester 3 dengan bobot 2 SKS yaitu 1 SKS teori dan 1 SKS praktek atau 150 menit kegiatan tatap muka. Sesuai dengan silabus mata kuliah Sulaman garis-garis besar materi pembelajaran yang dipelajari pada pembelajaran sulaman terdiri atas 


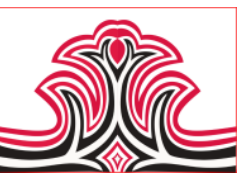

konsep dasar menghias busana, jenis-jenis teknik membuat benda hias busana, alat dan bahan serta tusuk hias, menyulam dengan teknik mengatur benang secara dekoratif.

Sulaman merupakan salah satu seni kerajinan yang banyak dijumpai dan memiliki keanekaragaman ragam hias. Sulaman adalah salah satu seni mengatur benang secara dekoratif diatas permukaan kain/bahan. Salah satu sulaman dengan menggunakan teknik mengatur benang secara dekoratif adalah sulaman timbul. Sulaman timbul merupakan salah satu sulaman khas di daerah Sumatera Barat. Sulaman timbul merupakan sulaman yang unik dimana sulaman ini memiliki kesan timbul atau menonjol dari permukaan kain. Sulaman timbul memiliki teknik dan cara yang berbeda dari sulaman lainnya, dimna salah satunya tidak bisa ditiru oleh mesin. Terdapat 2 teknik dasar membuat sulaman timbul, diantara tenik tusuk bulion dan teknik tusuk anyam.

Dari observasi yang penulis lakukan kepada mahasiswa yang telah mengambil mata Kuliah Sulaman pada 22 Mei 2018. Diketahui mahasiswa kesulitan dalam mengembangkan teknik sulaman dikarenakan mahasiswa masih bergantung pada dosen pembina mata kuliah sulaman dan media atau bahan ajar terkait dengan mata kuliah sulaman sangat minim, terutama pada materi yang khusus membahas tentang pembuatan sulaman timbul.

Sejalan dengan hasil wawancara kepada dosen pembina mata kuliah Sulaman pada tanggal 22 Mei 2018 dan 13 September 2018 dengan dosen pembina mata kuliah Sulaman. Diketahui bahwa sumber bacaan atau referensi maupun bahan ajar mengenai sulaman yang dapat dimanfaatkan oleh mahasiswa masih sedikit. Pada proses pembelajaran dikelas, media pembelajaran yang digunakan mahasiswa untuk belajar sulaman masih berupa jobsheet dan contohcontoh tugas mahasiswa sebelumnya, belum tersedianya bahan ajar mengenai sulaman timbul yang valid dan praktis. Buku-buku yang digunakan juga ada namun hanya beberapa dan hanya menjelaskan secara umum tentang macam-macam sulaman. Sehingga pada proses pembelajaran dikelas mahasiswa masih berpusat kepada dosen pembina mata kuliah, dan mahasiswa menjadi kurang mandiri dan termotivasi dalam mengembangkan teknik sulaman timbul.

Untuk itu diharapkan adanya media pembelajaran yang dapat dimanfaatkan mahasiswa dalam pembelajaran secara mandiri. Salah satu media pembelajaran yang dapat digunakan adalah bahan ajar.
Gorga Jurnal Seni Rupa

Volume 08 Nomor 01 Januari-Juni 2019

p-ISSN: 2301-5942 | e-ISSN: 2580-2380

Untuk menghasilkan bahan ajar pembelajaran yang berkualitas perlu dilakukan penelitian. Kualitas bahan ajar dapat dilihat dari hasil pengujian validasi yang dilakukan pada proses pengembangan bahan ajar, jadi dengan dihasilkannya bahan ajar yang sesuai, baik, valid dan praktis. Mahasiswa dapat belajar secara mandiri tanpa bimbingan dosen.

Untuk menghasilkan bahan ajar yang mampu memerankan fungsi dan perannya makanya materi tersebut harus berkualitas dan memudahkan proses pembelajaran dan mahasiswa dapat belajar dengan kreatif tanpa bergantung dosen pembimbing. Hal ini dapat dilihat dari hasil penguji validas dan praktikalitas yang dilakukan pada proses pengembangan bahan ajar sehingga menghasilkan bahan ajar yang valid, praktis. Bahan ajar ini diharapkan dapat membantu mahasiswa dalam melaksanakan proses belajar maupun menyelesaikan tugas-tugas yang diberikan, dapat memberikan konstribusi dan solusi untuk mengatasi kendalakendala yang ada, meningkatkan kualitas belajar mahasiswa, serta memberikan ruang lingkup sebagai sarana untuk belajar agar dapat menyesuaikan materi dan pembelajaran yang optimal.

Tujuan penelitian ini dilakukan untuk: Mendeskripsikan desain bahan ajar pembuatan Sulaman Timbul pada mata kuliah Sulaman mahasiswa Prodi (D3) Tata Busana Jurusan Ilmu Kesejahteraan Keluarga Fakultas Pariwisata dan Perhotelan Universitas Negeri Padang yang valid dan praktis, mendeskripsikan validitas bahan ajar pembuatan Sulaman Timbul pada mata kuliah Sulaman mahasiswa Prodi (D3) Tata Busana Jurusan Ilmu Kesejahteraan Keluarga Fakultas Pariwisata dan Perhotelan Universitas Negeri Padang, dan mendeskripsikan praktikalitas bahan ajar pembuatan Sulaman Timbul pada mata kuliah Sulaman mahasiswa Prodi (D3) Tata Busana Jurusan Ilmu Kesejahteraan Keluarga Fakultas Pariwisata dan Perhotelan Universitas Negeri Padang.

\section{KAJIAN TEORI}

\section{Bahan Ajar}

Salah satu media pembelajaran yang dapat dirancang untuk membantu kelancaran proses pembelajaran yaitu bahan ajar dimana masing-masing mahasiswa dapat belajar dengan baik dirumah dan dikampus secara individual bersifat mandiri. Hal ini sejalan dengan pendapat Purwanto (2005:6) yang mengemukakan: "Bahan ajar adalah bahan atau materi perkuliahan yang disusun secara sistematis yang digunakan dosen dan mahasiswa dalam proses 
perkuliahan. Bahan ajar mempunyai struktur dan urutan yang sistematis, menjelaskan tujuan instruksional yang akan dicapai, memotivasi mahasiswa untuk belajar, mengantisipasi kesukaran belajar mahasiswa dalam bentuk penyedian bimbingan bagi mahasiswa untuk mempelajari bahan tersebut, memberikan latihan yang banyak bagi mahasiswa, menyediakan latihan yang banyak, menyediakan rangkuman dan secara umum berorientasi pada mahasiswa secara indiviual bersifat mandiri”.

Sejalan dengan itu Sanjaya (2008:141) "Bahan atau materi pelajaran (Learning Materials) adalah segala sesuatu yang menjadi isi kurikulum yang harus dikuasai oleh mahasiswa sesuai dengan kompetensi dasar dalam rangka pencapaian standar kompetensi setiap mata pelajaran dalam satuan pendidikan tertentu".

Dari pendapat diatas dapat diketahui bahwa bahan ajar adalah bahan yang disusun oleh dosen dan dirancang sedemikian rupa yang bertujuan untuk memudahkan tugas dosen mengajar dan memotivasi mahasiswa dalam belajar, mengantisipasi kesukaran belajar mahasiswa dalam bentuk penyediaan bimbingan bagi mahasiswa untuk mempelajari bahan tersebut, memberikan latihan yang banyak bagi mahasiswa, menyediakan rangkuman, dan umum berorientasi pada mahasiswa secara individual bersifat mandiri yang terdiri dari terdiri dari pengetahuan, keterampilan dan sikap.

Depdiknas (2008:10) menyatakan bahwa "Tujuan penyusunan bahan ajar, yakni: 1) menyediakan sumber belajar yang memadai sesuai dengan kebutuhan siswa/mahasiswa, 2) membantu siswa/mahasiswa memperoleh alternatif sumber belajar yang lebih variasi di banding dengan buku teks yang kadang kaku dan sulit di perolah, 3) mendorong siswa/mahasiswa aktif dalam melaksanakan pembelajaran karena bahan ajar dapat dijadikan pedoman bagi siswa/mahasiswa untuk belajar mandiri, 4) menciptakan kegiatan pembelajaran yang lebih menarik dan bervariasi”.

Disimpulkan bahwa tujuan bahan ajar yaitu dapat menyediakan sumber belajar yang memadai sesuai dengan kebutuhan siswa/mahasiswa, dapat membantu siswa/mahasiswa memperoleh alternatif sumber belajar yang lebih variasi di banding dengan buku teks yang kadang kaku dan sulit di perolah, dapat mendorong siswa/mahasiswa aktif dalam melaksanakan pembelajaran karena bahan ajar dapat dijadikan pedoman bagi siswa/mahasiswa untuk belajar mandiri, dapat menciptakan kegiatan pembelajaran yang lebih menarik dan bervariasi, dari tujuan penyusunan bahan ajar diatas pada dasarnya dalah sebagai alat dan cara untuk mencapai kompetensi atau tujuan pembelajaran.

\section{Sulaman Timbul}

Sulaman tangan merupakan salah satu kerajinan yang memiliki keanekaragaman ragam hias. Menurut Ernawati, dkk (2008:384) Menghias dalam bahasa Inggris berasal dari kata "to decorate" yang berarti menghias atau memperindah suatu benda. Sedangkan menurut Yuliarma (2013:6) menjelaskan bahwa "Sulaman adalah suatu elemen untuk mengubah penampilan permukaan kain dengan aneka setik atau bordir, baik dibuat dengan tangan atau mesin".

Sejalan dengan itu Tamimi (1982:225), menyatakan sulaman adalah: "istilah menjahit, artinya menjahit benang secara dekoratif, untuk itu diperlukan tusuktusuk hias sesuai dengan jenis bahan yang dapat dihias". Namun menurut Sativa (1999:18), menyulam adalah "kepiawaian yang digambarkan, dirasa, dan dialami. Merupakan suatu kaji menyulam yang dapat menambah kedalaman pengertian seni dalam bentuk tersendiri"

Dari pendapat diatas dapat disimpulkan bahwa sulaman merupakan salah satu seni kerajinan yang banyak dijumpai dan memiliki keanekaragaman ragam hias. Sulaman adalah salah satu seni mengatur benang secara dekoratif diatas permukaan kain/bahan. Salah satu sulaman dengan menggunakan teknik mengatur benang secara dekoratif adalah sulaman timbul. Sulaman timbul merupakan sulaman yang unik dimana sulaman ini memiliki kesan timbul atau menonjol dari permukaan kain. Sulaman timbul memiliki teknik dan cara yang berbeda dari sulaman lainnya, dimana salah satunya tidak bisa ditiru oleh mesin. Terdapat 2 teknik dasar membuat sulaman timbul, diantara tenik tusuk bulion dan teknik tusuk anyam.

Teknik tusuk bullion merupakan bagian dari seni sulaman, yaitu salah satu bentuk sulaman yang berupa simpu dan memberi kesan timbul. Pada dasarnya, bullion sama seperti jenis sulaman lainnya dapat dibuat pada semua kain, namun pemakaian bullion saat ini banyak digunakan pada busana wanita dan lenan rumah tangga terutama bentuk bunga karena selain bentuknya yang indah juga memberi kesan amat alami dan sulit ditiru oleh mesin. Tusuk bullion adalah sebuah cara menyulam dengan melilit-lilitkan benang sulam ke jarum, sebelum benang dimasukkan kembali 


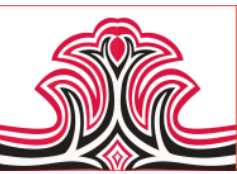

kedasar kain sehingga menghasilkan bentuk sulaman yang timbul dan bernilai tinggi.

Teknik tusuk anyam merupakan jahitan yang dibuat dengan menggunakan dua buah jarum tangan. Masingmasing jarum tangan dipasangkan benang, banyaknya helaian benang bergantung pada keinginan si pembuat. Jarum 1 menggunakan tiga helai benang dan jarum ke2 menggunakan tiga helai benang. Jarum 1 digunakan untuk membuat rangka anyaman sedangkan jarum ke2 digunakan untuk menganyam pada rangka anyaman yang telah dibuat. Bentuk sulaman timbul dengan tusuk anyam terbagi atas: bentuk bulat, melebar, lancip (melebar ditengah dan mengecil satu sisi), memanjang.

\section{METODE PENELITIAN}

Jenis penelitian yang digunakan pada penelitian ini adalah metode penelitian dan pengembangan atau yang lebih dikenal dengan Research and Development $(R \& D)$. Menjelaskan Penelitian dan pengembangan adalah rangkaian proses atau langkah-langkah dalam rangka mengembangkan suatu produk baru atau menyempurnakan produk yang sudah telah ada agar dapat dipertanggung jawabkan. Lokasi pada penelitian ini adalah di Jurusan IKK Prodi (D3) Tata Busana FPP-UNP. Sedangkan untuk subjek penelitian ini adalah dosen pembina mata kuliah Sulaman dan mahasiswa Jurusan IKK Prodi (D3) Tata Busana angkatan 2017 di Fakultas Pariwisata dan Perhotelan Universitas Negeri Padang.

Prosedur penelitian yang digunakan yakni model pengembangan 4D (Four-D), model ini terdiri dari 4 tahap pengembangan yaitu: Define (Pendefinisiaan), Design (Perancangan), Develop (Pengembangan), dan Disseminate (Penyebaran). Namun pada penelitian tahap dessminate (penyebaran) belum dapat dilakukan karena mengingat keterbatasan peneliti.

Tahap Pendefinisian (Define) merupakan tahap untuk menetapkan dan mendefenisikan syarat-syarat pembelajaran, terdiri dari: analisis ujung depan, analisis mahasiswa, analisis tugas, analisis konsep dan perumusan tujuan pembelajaran. Tahap Perancangan (Design) adalah tahap untuk menyiapkan prototipe perangkat pembelajaran, terdiri dari: a) Menganalisis materi mata kuliah yang akan dijadikan isi bahan ajar yang akan dibuat berpedoman kepada silabus pembelajaran, b) Melakukan studi pustaka untuk mencari sumber dalam merancang bahan ajar sulaman timbul, (c) Menetapkan kerangka bahan ajar atau garis-garis besar bahan ajar, (d) Mengembangkan
Gorga Jurnal Seni Rupa

Volume 08 Nomor 01 Januari-Juni 2019

p-ISSN: 2301-5942 | e-ISSN: 2580-2380

materi yang telah dirancang dalam kerangka bahan ajar, (e) Menyusun kerangka bahan ajar.

Tahap Pengembangan (Develop) merupakan tahap untuk menghasilkan perangkat pembelajaran yang sudah direvisi berdasarkan masukan dari para pakar. Tahap ini meliputi: tahap validasi, revisi dan tahap praktikalitas. Tahap validasi modul ini dilakukan oleh 4 orang validator yaitu: 2 orang ahli media dan 2 orang ahli materi. Tahap revisi dilakukan sesuai dengan masukkan dari ahli media dan ahli materi. Hasil revisi merupakan produk awal yang sudah tervalidasi, hal ini perlu dilakukan agar produk awal dapat disebut layak digunakan oleh mahasiswa ketika memasuki tahap uji coba. Tahap praktikalitas dilakukan dengan dosen mata kuliah, uji coba kelompok kecil, dan uji coba kelompok besar.

Terdapat dua macam uji coba yaitu uji coba kelompok kecil dan uji coba lapangan. Uji coba kelompok kecil adalah uji coba yang dilakukan hanya kepada 2-4 peserta didik, sedangkan uji coba lapangan adalah uji coba yang dilakukan kepada peserta dengan jumlah 25-30 peserta didik. Pada uji praktikalitas kelompok kecil diberikan kepada 4 orang mahasiswa, uji praktikalitas kelompok besar diberikan kepada 30 orang mahasiswa dan uji praktikalitas 1 orang dosen pembina mata kuliah Sulaman.

Jenis data yang diambil dalam penelitian ini adalah data primer. Data pertama berupa hasil validasi dari validator. Data kedua dari pelaksanaan uji praktikalitas mahasiswa dan dosen dalam menggunakan bahan ajar pembuatan sulaman timbul. Teknik pengumpulan data dapat dilakukan dengan cara: observasi dan angket. Teknik analisis data berdasarkan analisis validitas dan analisis praktikalitas modul pembelajaran.

\section{HASIL DAN PEMBAHASAN \\ 1.Hasil}

\section{1).Desain Bahan Ajar}

Tahap perancangan (design) bahan ajar membuat sulaman timbul mata kuliah Sulaman ini merujuk pada prosedur penulisan bahan ajar yang terdiri dari:

\section{(1).Analisis Kebutuhan Bahan Ajar}

Pada tahap ini penulis menganalisis materi mata kuliah yang akan dijadikan isi bahan ajar. Materi yang dipilih adalah tentang pembuatan sulaman timbul pada mata kuliah sulaman yang penulis tetapkan menjadi judul bahan ajar. Untuk mempelajari materi ini membutuhkan waktu 2 kali pertemuan tatap muka. Waktu yang tersedia untuk 1 kali pertemuan adalah 


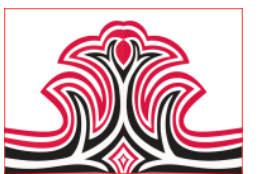

150 menit, sehingga total jam pembelajaran yaitu 2x150 menit.

\section{(2).Menetapkan Kerangka Garis-garis Besar Bahan Ajar}

Pada tahap ini penulis menentukan jumlah materi pembelajaran, menentukan judul dan tujuan pada setiap kegiatan pembelajaran yang ada didalam bahan yang akan dibuat. Proses menetapkan kerangka bahan ajar disesuaikan dengan silabus mata kuliah Sulaman. Adapun bahan ajar yang dirancang terdiri dari 3 materi pembelajaran yang memiliki judul sebagai berikut: a. Pengenalan Sulaman Timbul, b. Persiapan Menyulam, c. Langkah Kerja Sulaman Timbul.

\section{(3).Menyusun Kerangka Bahan Ajar}

Penyusunan kerangka bahan ajar ini bertujuan agar materi pembelajaran yang terdapat pada bahan ajar dapat disaji secara sistematis dan berurutan sehingga siap dipelajari oleh mahasiswa. Susunan kerangka bahan ajar pembelajaran yang dirancang dimodifikasi dari kerangka penulisan bahan ajar menurut Atwi Suparman dalam Purwanto (2005:23).

\section{a.Uji Validasai Bahan Ajar}

Tahap validitas modul ini dinilai oleh 4 validator, yakni 2 validator media yang menilai dalam segi kelayakan media, sedangkan 2 validator materi menilai terhadap kelayakan materi yang dipilih.

Hasil data dari validator ahli media diperoleh skor rata-rata 4,49 dengan kategori sangat valid, sedangkan hasil data dari validator materi diperoleh skor rata-rata 4,21 dengan kategori sangat valid. Jadi rekapitulasi dari validator media dan materi diperoleh skor ratarata 4,35 dengan kategori sangat valid.

\section{b.Uji Praktikalitas Bahan Ajar}

Tahap praktikalitas dilakukan dengan melakukan uji coba praktikalitas kepada dosen pembina mata kuliah dan mahasiswa untuk melihat kemudahan dalam penggunaan bahan ajar yang digunakan. Data uji praktikalitas bahan ajar pembuatan Sulaman Timbul diambil melalui angket.

Uji praktikalitas oleh dosen pembina mata kuliah diperoleh skor $83 \%$ dengan kategori sangat praktis. Sedangkan uji Praktikalitas mahasiswa kelompok kecil dengan jumlah 4 orang diperoleh skor $85 \%$ dengan kategori praktis. Selanjutnya hasil data uji praktikalitas pada responden mahasiswa kelompok besar dengan jumlah 30 orang diperoleh skor $82 \%$ dengan kategori sangat praktis. Jadi rekapitulasi dari
Gorga Jurnal Seni Rupa

Volume 08 Nomor 01 Januari-Juni 2019

p-ISSN: 2301-5942 | e-ISSN: 2580-2380

uji praktikalitas oleh mahasiswa dan dosen mata kuliah adalah $83 \%$ dengan kategori sangat praktis.

\section{Pembahasan \\ 1).Desain Bahan Ajar}

Bahan ajar yang dimaksud adalah sebuah media pembelajaran yang berbentuk media cetak (hardcopy). Bahan ajar disajikan dengan menggabungkan teks dan gambar berwarna yang dibuat menarik agar dapat meningkatkan minat mahasiswa untuk belajar. Bahan ajar ini menggunakan format kertas secara vertikal dengan ukuran $\mathrm{A} 4$, dan memiliki 100 halaman yang terdiri dari tiga materi pembelajaran dan dilengkapi dengan rangkuman dan tes evaluasi pada setiap akhir materi pembelajaran. Pada bagian akhir terdapat tes formatif dan tes sumantif yang dilengkapi dengan kunci jawaban, senarai, daftar pustaka.

Bahan ajar dikatakan layak apabila memiliki karakteristik yaitu self instructional, self contained, stand alone, adaptive, dan user friendly. Bahan ajar yang berbentuk media cetak akan memudahkan mahasiswa untuk belajar tidak hanya saat pembelajaran, namun bisa dirumah atau dimana saja.

Bahan pembelajaran yang disusun hendaknya memiliki derajat keterbacaan yang tinggi, dalam arti bahasa yang disajikan menggunkan struktur kalimat dan kosa kata yang baik, bentuk kalimat sesuai tata bahasa, dan isi pesan yang disampaikan melalui huruf, gambar, dan ilustrasi mempermudah dalam penyajian pesan. Hal tersebut didukung pernyataan mengatakan bahwa dalam mengembangkan suatu produk berupa bahan ajar harus mampu untuk meningkatkan motivasi peserta didik dan efektif dalam mencapai kompetensi yang diharapkan sesuai dengan tingkat kompleksitasnya.

\section{(1).Validitas Bahan Ajar}

Tahap validasi dilakukan untuk menghasilkan bahan ajar pembuatan sulaman timbul yang layak dan sesuai dengan kebutuhan mahasiswa sehingga dapat digunakan dalam perkuliahan Sulaman. Hasil validitas terhadap bahan ajar pembuatan sulaman timbul pada mata kuliah Sulaman yang dihasilkan menunjukkan hasil yang valid dengan revisi dan perolehan skor ratarata adalah 4,35 dengan kategori sangat valid. Beberapa aspek yang diamati dalam uji validitas adalah media dan materi.

Validasi bahan ajar bertujuan untuk memperoleh pengakuan atau pengesahan kesesuaian bahan ajar dengan kebutuhan sehingga bahan ajar tersebut layak dan cocok digunakan dalam pembelajaran. Apabila 


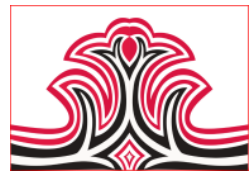

media pembelajaran berupa bahan ajar sudah dinyatakan valid maka bahan ajar dapat disebarkan dan digunakan pada proses perkuliahan mata kuliah Sulaman.

\section{(2).Praktikalitas Bahan Ajar}

Praktikalitas merupakan tingkat keterpakaian perangkat pembelajaran, dengan malakukan uji coba menggunakan bahan ajar yang telah dinyatakan valid oleh validator. Tahap praktikalitas dilakukan setelah bahan ajar dinyatakan valid atau layak oleh validator. Berdasarkan data praktikalitas bahan ajar yang diperoleh dari respon dosen pembina dan mahasiswa dapat disimpulkan bahwa hasil penilaian uji praktikaliatas pengembangan bahan ajar sulaman timbul kuliah Sulaman diperoleh hasil yaitu $\mathbf{8 3 \%}$ dengan kategori sangat praktis.

Jika modul sudah dinyatakan praktis, maka dapat dikatakan modul tersebut sudah layak digunakan sebagai media pembelajaran pembuatan sulaman timbul pada mata kuliah Sulaman. Perangkat pembelajaran dikatakan praktis jika mahasiswa tersebut tidak kesulitan belajar. Jika hasil belum praktis, maka dilakukan perbaikan sehingga perangkat pembelajaran dinyatakan praktis.

Berdasarkan uji validitas dan uji praktikalitas yang dilakukan bahan ajar pembuatan sulaman timbul ini memberikan manfaat bagi mahasiswa khususnya untuk belajar mandiri pada mata kuliah Sulaman.

\section{KESIMPULA DAN SARAN}

\section{Kesimpulan}

Bahan ajar yang dikembangkan adalah sebuah media pembelajaran berbentuk media cetak (hardcopy) yang disajikan dalam bentuk teks dan gambar yang menarik dan full color yang dapat menigkatkan motivasi belajar mahasiswa. Bahan ajar ini terdiri dari 100 halaman yang terdiri dari 3 kegiatan pembelajaran dan dilengkapi dengan rangkuman dan tes evaluasi pada setiap akhir kegiatan pembelajaran. Pada kegiatan akhir terdapat tes formatif dan tes sumantif yang dilengkapi dengan kunci jawaban dan daftar pustaka.

Validitas Bahan Ajar Pembelajaran berdasarkan ahli materi dan ahli media dinyatakan valid dengan skor rata-rata 4,35

Praktikalitas Bahan Ajar Pembelajaran berdasarkan dosen pembina mata kuliah dan mahasiswa dinyatakan valid dengan skor $83 \%$, sehingga bahan ajar
Gorga Jurnal Seni Rupa

Volume 08 Nomor 01 Januari-Juni 2019

p-ISSN: 2301-5942 | e-ISSN: 2580-2380

pembelajaran dapat digunakan oleh mahasiswa sebagai media pembelajaran.

\section{Saran}

Berdasarkan hasil penelitian yang telah penulis lakukan, maka penulis menyarankan hal-hal sebagai berikut:

Bagi mahasiswa diharapkan dapat memanfaatkan Bahan Ajar Pembuatan Sulaman Timbul Mata Kuliah Sulaman ini secara optimal sebagai penunjang dalam proses pembelajaran.

Bagi dosen yang mengajarkan mata kuliah Sulaman diharapkan agar dapat memanfaatkan bahan ajar pembelajaran ini dan mengimplementasikannya dalam pembelajaran.

Bagi penelitian selanjutnya yang sejenis tentang Bahan Ajar Pembuatan Sulaman Timbul Mata Kuliah Sulaman dapat membuat bahan ajar dengan berbagai macam spesifikasi program sejenis dengan lebih kreatif, inovatif dan terperinci sehingga dapat menambah sumber belajar yang dapat digunakan oleh mahasiswa.

\section{DAFTAR RUJUKAN}

Ernawati,dkk.(2008). Tata Busana Jilid 2. Jakarta: Direktorat Pembinaan Sekolah Menengah Kejuruan.

Depdinas. (2008). Teknik Penyusunan Modul. Jakarta: Direktorat Jendra Manajemen Pendidikan Dasar dan Menengah, Departemen Pendidikan Nasional.

Purwanto. (2005). Applied Approach Mengajar di Perguruan Tinggi. Jakarta: PPU-PPAI-UT

Sanjaya, Wina. (2008). Perencanaan dan Desain Sistem Pembelajaran. Jakarta: Kencana Prenada Media Group.

Sativa, Sutan Azwar. (1999). Antakesuma Suji dalam Adat Minangkabau, Antakesuma Embrodery In The Minangkabau Adat. Jakarta. Djambatan.

Tamimi, E. (1982). Terampil Memantas Diri dan Menjahit. Jakarta: Depdik-bud.

Yuliarma. (2013). Desain Ragam Hias Sulaman dan Bodir, Desain Motif Dasar. Jurusan Kesejahteran Keluarga Fakultas Teknik Universitas Negeri Padang. Padang:- 